INTERNATIONAL JOURNAL OF ENTREPRENEURIAL KNOWLEDGE

Issue 1, volume 8, ISSN 2336-2960 (Online)

www.ijek.org

\title{
CSR ACTIVITIES IN THE CZECH SME SEGMENT
}

\author{
Zdenko Metzker \\ Tomas Bata University in Zlín, Faculty of Management and Economics, Zlín, Czech Republic \\ Email: z_metzker@utb.cz \\ Justas Streimikis \\ Lithuanian Institute of Agrarian Economics, Division of Farm and Enterprise Economics, Vilnius, Lithuania \\ Email: justas.streimikis@gmail.com
}

Received: 3 May 2020. Revision received: 28 May 2020. Accepted: 6 June 2020

\begin{abstract}
The aim of the study is to find out the perception of the concept of corporate social responsibility (CSR) by the segment of small and medium-sized enterprises in the Czech Republic. In connection with the objectives of the study, a questionnaire survey was carried out on a sample of 419 respondents - business owners and managers. The data were collected from September 2019 to January 2020. $\chi^{2}$ and Z-score were used to assess the hypotheses. It was found that there were statistical differences in the perception of some aspects of the positive impact of the introduction of the CSR concept in case of monitoring responses based on the geographic scope of the business. The results showed that although the manager should take into account the ethical and moral implications of his decisions, less than half of the respondents are familiar with the concept of CSR and enforce it in their management practice and ultimately managers cannot identify positive benefits from CSR implementation - it declares positive answers whose values oscillate around $30 \%$. The findings show that there are no statistically significant differences in the answers of managers depending on the size of the company - this proves that micro, small and medium enterprises, respectively their managers do not differ in their attitudes to the topic of CSR. The final effect of the paper is to show the perception of the concept of CSR of entrepreneurs - respondents in the Czech Republic.
\end{abstract}

KEYWORDS: corporate social responsibility, small and medium-sized enterprises, business environment in the Czech republic, CZECH SMEs segment, attitudes of entrepreneurs to CSR

JEL CLASSIFICATION: L11, L20, L26, L53, M14

Reference: Metzker, Z., Streimikis, J. (2020). CSR activities in the Czech SME segment. International Journal of Entrepreneurial Knowledge, 8(1), 49-64. doi: 10.37335/ijek.v8i2.101

\section{INTRODUCTION}

The concept of corporate social responsibility (CSR) in the segment of small and medium-sized enterprises (SMEs) is a current topic in the field of scientific research activities for several reasons. CSR and its application in SMEs management means that a small company, in addition to economic activities that are focused on its survival and development, pays attention to solving problems outside the economic system, environmental problems, respectively social problems, being determined by certain barriers to the development of economic activities.

SMEs have a relatively small economic power, also they have complicated access to external financial resources due to their internal characteristics, in the context of their financial performance usually do not have the best employees, which limits their economic opportunities. In this context, Chládková (2015) states that SMEs have unique characteristics that allow them to take a special position in the economic system. On the one hand, we generally have limited capital resources, on the other hand, these companies are very flexible in responding to change. 


\section{INTERNATIONAL JOURNAL OF ENTREPRENEURIAL KNOWLEDGE}

Issue 1, volume 8, ISSN 2336-2960 (Online)

www.ijek.org

Based on the report on the development of the business environment in the Czech Republic in 2018 (Ministry of industry and trade of the Czech Republic, 2019), out of the total number of 1,154,687 legal persons and individuals performing business activities, 1,152,735 were SMEs (99.83\%).

The presented work examines the perception of corporate social responsibility (CSR) by small and medium-sized enterprises (SMEs) operating in the Czech Republic. Data from companies were obtained through a comprehensive questionnaire survey, which focused on management, business risks and the decline of small and medium-sized enterprises. Data collection took place in the period from September 2019 to January 2020.

The structure of the article is following: the theoretical part presents the results of the literature search in the field of CSR in the international context and the results of some research from abroad, which can be confronted with the results of research conducted in the Czech Republic. The next part of the article presents the aim of the work, methodology and scientific hypotheses. In the results section, we present not only the results, but also the comparison with other studies. In the end, the basic results of the research are formulated.

\section{THEORETICAL REVIEW}

The European Commission (2011) defines corporate social responsibility as the responsibility of companies for their impact on society. In order to fully meet these requirements, businesses should have a process in place that allows them to integrate social, environmental, ethical, consumer, and human rights aspects into their business operations, and a core strategy in close cooperation with their stakeholders to maximize creating common values for owners / shareholders and other stakeholders and society as a whole, and identifying, preventing and mitigating their possible adverse effects.

The OECD (2001) states that the basic elements of CSR are business investment, which will provide jobs, ensure the production of goods and services to meet consumer needs and work to bring companies the overall well-being and improve the living standards of the population - thus providing better returns to their shareholders. / owner.

Caroll (2016) considers CSR to be a concept of philanthropy, ethics, legal and economic areas of businesssociety relations. Economic responsibility consists in creating added value (profit generation) and thus brings the company benefits to all parties involved. Legal responsibility represents compliance with regulations and laws that require companies to operate and conduct their business, established by the company. Society expects ethical responsibility for corporations to do what is right and fair. Taking ethical responsibility means that organizations adopt the activities, standards and practices that are expected, even if they are not clearly defined by law. Corporate philanthropy includes voluntary activities of the company. It is governed by a certain desire of the company to participate in the activities of the company - business environment, which are generally not expected to do business in an ethical sense. That is, they want to do what is right for society.

According to Porter and Kramer (2006), CSR is supported by four components -moral obligation (the corporation should be a good citizen and do the right thing), sustainability (focus on the environment and the community), law enforcement and reputation (increasing the company's reputation, image, brand value and even stock valuation improvements).

In today's world of globalization, businesses are no longer able to engage in destructive and unethical business practices, such as unfair work practices or environmental pollution, without receiving a negative reaction from the public (Krajnakova et al., 2018). The problem of responsible business in the era of 


\section{INTERNATIONAL JOURNAL OF ENTREPRENEURIAL KNOWLEDGE}

Issue 1, volume 8, ISSN 2336-2960 (Online)

www.ijek.org

globalization is largely concerned with trade relations, including the complex supply chain. It is necessary for the corporation to define the social obligations of its actions and the steps taken by other entities (Kowalska, 2016).

Tetřevová et al. (2017) say that corporate social responsibility is a certain behavior of managers and other employees of the company, which, in addition to economic and technical interests, respect the interests of corporate stakeholders, but this procedure is carried out beyond the law, voluntarily and permeates all corporate activities.

CSR is a corporation's contribution to sustainable development, but also a tool for building prestige, improving satisfaction and loyalty of stakeholders, thus helps to increase the value of the company. In recent decades, CSR has been a key factor in showing the impact of a company's activities on the environment and what social problems it can help alleviate through charitable activities (GorgenyiHegyes, Fekete Farkas, 2019).

The concept of CSR can be understood as a balanced style of management between asset and risk management, taking into account the benefits of all stakeholders (consumers, employees, suppliers, etc.) (Hadj, Omri, Al-Tit, 2020). Implementing the CSR concept is useful for businesses to mitigate the negative effects of their activities on the environment, as businesses contribute to environmental degradation (Bikefe et al., 2020).

Yunus and Weber (2010) explain that CSR programs are most often used to build a good corporate image, a certain presentation that the company is a "good neighbor", respectively "responsible member of the community", which, however, has nothing to do with the so-called "social entrepreneurship". The authors determine this by saying that social entrepreneurship is directly devoted to changing the social and economic situation of the poor population, respectively create continuous social improvement in the world. According to them, a profit-oriented company involved in the CSR concept can devote 95\% of resources to profit production and $5 \%$ or less to make the world a better place, in contrast to social entrepreneurship, where $100 \%$ of resources are allocated for this purpose. Various factors that play a key role in the development of the CSR are government initiatives, globalization and stakeholder involvement, and an extremely volatile economic business environment. (Krajnakova et al., 2018).

Pavlík and Bělč́k (2010) define the following benefits in the implementation of the CSR concept: increasing the intangible assets of the entire organization (image, reputation, brand value,...); cost savings in the long term (CSR activities lead to innovations that reduce explicit costs, in the context of implicit costs they can also contribute to their reduction); increasing profits in the long term; quality and satisfied loyal customers; gaining a competitive advantage and increasing customer loyalty; attracting investors, etc.

In their study, Flammer and Luo (2017) suggested that companies improve their social responsibility by bringing the following benefits: improving employee performance and helping to manage adverse employee behavior; differentiation from competition; improving the reputation and image of the company.

The concept of CSR has a number of opponents who are skeptical about this strategy. Kuldová (2010) explains that the company should admit that CSR is not a goal, but just a tool - being a successful socially responsible company becomes a company's strategy. From the point of view of the economic theory of monetarism (neoliberalism), Friedman states in his theory of stakeholders that CSR restricts the freedom of society and thus reduces economic freedom. The manager of the company must act in such a way that it does not conflict with other stakeholders, e.g. when acting in the public interest in the context of CSR, it reduces the returns for shareholders and thus decomposes the very purpose of the business (Friedman, 


\section{INTERNATIONAL JOURNAL OF ENTREPRENEURIAL KNOWLEDGE}

Issue 1, volume 8, ISSN 2336-2960 (Online)

www.ijek.org

1993). According to Friedman, the sole social responsibility of the entrepreneur is to use his resources and carry out activities to achieve and generate profit as long as they remain within the limits of the "rules of the game", as long as it is within the law and there is no resort to fraud and deception. CSR does not mean that companies should give up their main economic goal, which is to make a profit. This does not mean that socially responsible companies can be more profitable than less responsible companies (Krajnakova et al., 2018).

Proponents of the CSR concept respond to Friedman's criticism in that industrial society faces serious societal problems caused mainly by the emergence of global corporations - managers must manage the company's activities to solve these problems, respectively at least they eased. Thus, CSR will reduce the need for regulation by the state (Pavlík and Bělčík, 2010).

Gelbman (2010) points out that the CSR model applicable to SMEs is still lacking: the tools that SMEs need to cope with the task of using CSR will be different from the previously formalized tools used by larger companies. Different SMEs may have different understandings of CSR, which differ from the different components of CSR. Basically, there is no "universal" model for the overall integration of CSR.

In the Czech Republic, elements of CSR appear in the interwar period, where Tomáš and Ján Antonín Bat'a are most often mentioned, where a number of authors believe that social responsibility is one of the main features of Bat'a company (Kašparová, Kunz, 2013). The development of CSR in Czechoslovakia was, in its essence, which we understand according to the definition of the European Commission, interrupted. According to Prskavcová et al. (2007) introduced the term "corporate social policy" during this period, which provided a number of social activities with the help of state subsidies. The expansion of CSR in the Czech Republic is mainly due to large corporations. Kunz (2012) adds that if the potential of CSR is to be fully exploited, it must not become the prerogative of only large companies, but of the entire business environment.

Kunz (2012) states that in 2006 a questionnaire survey was conducted by the Business Leaders Forum with a focus on the use of CSR by Czech small and medium-sized enterprises. The target group were companies based in the capital city of Prague. One of the results was the aspect that more than $85 \%$ of respondents carry out some activity in the field of CSR with an ethical-moral motive.

Further research carried out by the Business Leaders Forum in Prague in 2008, described by Kunz (2012), showed that knowledge of the CSR concept is lower in the context of SMEs than asin large companies. In the case of small companies, 37\% encountered the concept of CSR, in the case of medium-sized companies $61 \%$, in the case of large companies it was up to $97 \%$.

The 2019 CSR and reputation research 2019 (Ipsos, 2019), focused on the aspect of corporate social responsibility in the eyes of the Czech population, states that for $52 \%$ of respondents is important whether the company from which they are buying the products is socially responsible. According to $51 \%$ of respondents support under the CSR concept should be focused on environmental protection and 48\% on fair treatment of employees.

The same research in 2016 CSR and reputation research 2016 (Ipsos, 2017) in the Czech Republic found that $35 \%$ of respondents imagine a socially responsible company in their area (24\% in 2015). For $79 \%$ of employees in companies, it is important that their employer is socially responsible. Employees from the CRS concept come first with fair treatment of employees ( $47 \%$ of respondents) and environmental protection ( $46 \%$ of respondents).

According to Jones (2014), the basic factor of sustainability and a more socially responsible future is the approach of investors and shareholders, whose focus is on results (economic) rather than sustainable 


\section{INTERNATIONAL JOURNAL OF ENTREPRENEURIAL KNOWLEDGE}

Issue 1, volume 8, ISSN 2336-2960 (Online)

www.ijek.org

development and CSR. The greatest profits and the greatest successes will increasingly be achieved by companies that demonstrate their ability to create value through a socially responsible approach (Jones, 2014, p. 186).

Many authors unite in the organization's activities in the field of CSR. These are mainly sponsorship (requiring some consideration from the sponsor - fulfillment of the sponsor's marketing goals (Pavlík and Bělćík, 2010)) and donation; creation of corporate foundations and endowment funds; social marketing, consisting of companies' campaigns to commit to contributing to a specificnon-profit organization; reporting of social responsibility or other forms of support (in-kind community support, offer of professional help, etc.).

In the context of SMEs, Lee, Herold and Yu (2016) differentiate approaches to CSR between large companies and SMEs. For small and medium-sized enterprises, the following applies: liability to a smaller number or different stakeholders; responsibility especially towards the local (often small) community; SMEs often have no shareholders; customer pressure in the supply chain; informal planning of CSR strategy; emphasis on intuition and ad hoc processes; most of them do not have specialists for CSR implementation; small-scale activities (e.g. support for a local sports club); activities are often not recognized as related to CSR.

Their research on Swedish SMEs found that the implementation of the CSR concept is strongly dependent on the personal value and initiative of the owner. The overall intention of the owner to adopt CSR is to protect, maintain and develop their business. SME owners (entrepreneurs) prefer the "profitoriented CSR" path rather than the "profit-sacrificing CSR". However, the results show that the approach to CSR performance is rather informal and lacks strategy. In terms of the overall impact on the business, the intended profit strategy to be achieved will in fact be transformed into a profit-sacrificing activity. Instead of increasing sales, CSR performance has a negative impact on business performance.

Research by Hodinková and Sádovský (2016) shows that the main benefits of introducing CSR in SME business practice include increased attractiveness for investors, strengthening the market position, increasing resource cost savings and increasing efficiency, especially in the economic field; in the social field: increasing trust, achieving a higher level of transparency, improving the good name of entrepreneurs, improving employer-employee and supplier-client relations, increasing employee motivation, increasing the attractiveness for quality employees, strengthening employee loyalty; in the field of the environment: reduction of environmental pollution and reduction of resource consumption.

Regarding the implementation of CSR in small and medium-sized enterprises in the Czech Republic, they emphasize the importance of looking at this issue as an opportunity to improve their performance and ensure the sustainability of their business activities. Only the ability to identify opportunities for SMEs in the form of CSR implementation can give these entrepreneurs a competitive advantage. At present, the introduction of CSR in small and medium-sized enterprises is very limited.

Research on CSR in family SMEs in China, published by Xue, Yu, Xu (2019), showed that in terms of overall knowledge of CSR, $96 \%$ of participants said they had heard of CSR or equivalent concepts. The most important parameters of CSR were health and safety and the business environment. In terms of knowledge, participants from different industries had different knowledge of CSR and focused on different parameters. More than $91 \%$ of participants disagreed that companies should not be involved in CSR.

The most frequently performed activities in the field of CSR were charitable donations (81\%), acceptance of charitable organizations or other non-profit organizations $(73 \%)$, education and development of employees $(63 \%)$ and care of employees $(60 \%) .31 .38 \%$ of corporations had a budget for CSR-related 


\section{INTERNATIONAL JOURNAL OF ENTREPRENEURIAL KNOWLEDGE}

Issue 1, volume 8, ISSN 2336-2960 (Online)

www.ijek.org

programs. More than half $(54.27 \%)$ did not have a budget, but planned to set one up separately for CSRrelated activities.

In France, research (Vo, Delchet-Cochet, Akeb, 2015) revealed that the economic motive has the highest level of influence in encouraging French SMEs to integrate CSR into their business strategy, followed by the social motive. Only a proactive environmental motive plays a role in environmental protection measures, indicating the extent to which a company is transforming its business and environmental activities (the practice of proactive environmental protection can potentially lead to a competitive advantage through the development of green products).

Research in England in 2003 on the feasibility of CSR for SMEs showed (Castka, Balzarova, Bamber, Sharp) that the vast majority of SMEs believe that organizations as such should pay close attention to their social and environmental responsibilities. The social and community activities of SMEs are vague and informal, and few have or feel the need for formal policies or stated intentions. Many companies are involved with at least the part that covers CSR, and the main reasons for the initial and continued involvement of SMEs in the CSR concept are based on the personal interest of the owner / management. The main obstacles to further implementation are concerns about bureaucracy, time and costs (these barriers are based on perception rather than reality). The cooperation of third parties is also important.

Nowadays, there is a growing pressure on corporate social responsibility (Chen et al., 2019). Acting in accordance with the principles of CSR brings many benefits and profits - mostly of a non-financial nature, which become important for the quality and sustainable operation of the corporation. Using various CSR activities, SMEs can also offer potential employees benefits that will ensure their interest and subsequent loyalty. Also, in supplier-customer relationships, CSR influences some companies in the choice of their business partners. For the company itself, its good reputation in the area in which it operates is of great importance (Lu et al., 2019). Therefore, the topic of CSR is current and according to the moods in the company will constantly gain in importance. It is therefore appropriate to determine the state of knowledge and use of the concept of CSR by small and medium-sized enterprises in the Czech Republic and to find out their perception of positive aspects and benefits for the company.

\section{AIM AND METHODOLOGICAL BASES}

The aim of the paper is to present the significant attributes of CSR in the SME sector in the Czech Republic and to compare the attitudes of entrepreneurs in this area in terms of size and domicile of the company.

The questionnaire survey involved 419 representatives of small and medium-sized enterprises in the Czech Republic, of which 274 were micro-enterprises (up to 9 employees), 92 small enterprises (10 - 49 employees) and 53 medium-sized enterprises (up to 249 employees). In percentage terms, 65\% are microenterprises, $22 \%$ are small enterprises and $13 \%$ are medium-sized enterprises. A total of 7,900 managers - entrepreneurs were contacted over a period of 5 months with a return of $5.3 \%$ of responses.

From the geographical distribution by region, we present the following structure of respondents (percentage expressions rounded to whole numbers): The capital city Praha 57 (14\%), South Bohemian region 32 (8\%), South Moravian region 26 (6\%), Karlovy Vary region 21 (5\%), Hradec Králové region 13 (3\%), Liberec region 29 (7\%), Moravian-Silesian region 52 (13\%), Olomouc region 31 (7\%), Pardubice region 30 (7\%), Pilsen region 21 (5\%), Central Bohemian region 30 (7\%), Ústí nad Labem region 29 (7\%), Vysočina region $22(5 \%)$ and Zlín region $26(6 \%)$. For the purposes of this work, we state that $284(68 \%)$ companies were included in the category Bohemia and $135(32 \%)$ companies in the category Moravia, selected by us. 


\section{INTERNATIONAL JOURNAL OF ENTREPRENEURIAL KNOWLEDGE}

Issue 1, volume 8, ISSN 2336-2960 (Online)

www.ijek.org

When differentiating into the length of doing business, $25(6 \%)$ have been in business for less than 3 years, 28 addressed SMEs have been in business for 3-5 years (7\%), 56 (13\%) for 6-10 years and 310 respondents $(74 \%)$ have been in business for over 10 years. $327(78 \%)$ of the respondents were the owner of the company, the other respondents - $92(22 \%)$ were managers in companies.

According to the sex of the respondents, 122 women (29\%) and $297(71 \%)$ men. Age structure of respondents: up to 35 years 64 (15\%), 36-45 years 96 (23\%), 46-55 years $104(25 \%)$, more than 55 years $155(37 \%)$.

In the case of the relationship between business and respondents qualification, the structure is following: education is related to business $160(38 \%)$, to some extent business is related to qualification 143 (34\%), $116(28 \%)$ respondents do business in an area unrelated to their qualifications. According to the maximum achieved education, the respondents stated that $39(9 \%)$ have completed secondary education without a GCSE, $170(41 \%)$ secondary with a GCSE, 33 (8\%) bachelor's, $157(37 \%)$ master's education and $20(5 \%)$ respondents has been awarded the degree of Ph.D.

The attitudes of Czech SMEs were examined in relation to the following claims:

- T1: The owner (manager) should take into account the moral and ethical implications of his decisions.

- T2: I know the concept of corporate social responsibility (CSR) and promote it in my managerial work

- T3: CSR implementation allows our company to gain a competitive advantage in the market and higher customer loyalty

- T4: CSR enables our company to acquire satisfied, loyal and motivated employees.

- T5: In which areas does your company operate responsibly?

Respondents were able to give the following answers: strongly agree, agree, disinterested, disagree, strongly disagree.

In the T5 statement, the respondents could state at least one, respectively a maximum of 3 answers from the following statements:

- the quality of our products is high, we adhere to the code of ethics in the company, we provide clear and truthful information, we are ethical in advertising, we produce products that do not harm the environment and do not harm the health of the population

- work environment (our employees work in a favorable work environment, we take care of employee development and education, we help mothers and parents, we provide equal opportunities for men and women, we care about the health and safety of our employees, we provide employees with various benefits)

- environment (our products are ecological, we use ecological packaging, we support waste recycling, we save energy, water, material, paper, etc., we minimize waste and protect natural resources)

- community (we treat the community in which we do business with consideration and fairness, we know the problems of the community in which we do business and we help them solve them, we support corporate donations and volunteering)

The following hypotheses were defined in the research:

- H1a: More than 50\% of SME owners (managers) agree that the owner (manager) should take into account the moral and ethical implications of their decisions. 
INTERNATIONAL JOURNAL OF ENTREPRENEURIAL KNOWLEDGE

Issue 1, volume 8, ISSN 2336-2960 (Online)

www.ijek.org

- H1b: There are statistically significant differences in the attitudes of owners (managers) towards T1 depending on the size of the company.

- H1c: There are statistically significant differences in the attitudes of the owner (manager) to T1 depending on the geographical location of the company (Moravia, Bohemia).

- H2a: More than 50\% of SME owners (managers) agree with the statement that they know CSR and promote it in their managerial work.

- H2b: There are statistically significant differences in the attitudes of owners (managers) towards T2 depending on the size of the company.

- H2c: There are statistically significant differences in the attitudes of the owner (manager) to T2 depending on the geographical location of the company (Moravia, Bohemia).

- H3a: More than 50\% of SME owners (managers) agree with the statement that the implementation of CSR allows the company to gain a competitive advantage in the market and higher customer loyalty.

- H3b: There are statistically significant differences in the attitudes of owners (managers) towards T3 depending on the size of the company.

- H3c: There are statistically significant differences in the attitudes of the owner (manager) towards T3 depending on the geographical location of the company (Moravia, Bohemia).

- H4a: More than 50\% of SME owners (managers) agree with the statement that CSR enables our company to acquire satisfied, loyal and motivated employees.

- H4b: There are statistically significant differences in the attitudes of owners (managers) towards T4 depending on the size of the company.

- H4c: There are statistically significant differences in the attitudes of the owner (manager) towards T4 depending on the geographical location of the company (Moravia, Bohemia).

\section{RESULTS}

The owner (manager) should take into account the moral and ethical implications of his decisions

Based on questionnaire research data, almost $90 \%$ of respondents (377) agree that the owner (manager) should take into account the moral and ethical implications of their decisions. Based on the data, we accept hypothesis H1a.

Table 1 The structure of answers to hypothesis $\mathrm{H} 1 \mathrm{~B}$

\begin{tabular}{|c|c|c|c|c|c|c|c|c|}
\hline & \multicolumn{2}{|c|}{$\begin{array}{c}\text { TOTAL } \\
419\end{array}$} & \multicolumn{2}{|c|}{$\begin{array}{c}\text { MICRO } \\
\text { ENTERPRISE } \\
274\end{array}$} & \multicolumn{2}{|c|}{$\begin{array}{c}\text { SMALL AND } \\
\text { MEDIUM } \\
\text { ENTERPRISE } \\
145\end{array}$} & \multirow[t]{2}{*}{ Z-score } & \multirow[t]{2}{*}{$\begin{array}{l}\mathrm{Z} \text {-score } \\
\text { p-value }\end{array}$} \\
\hline & No. & $\%$ & No. & $\%$ & No. & $\%$ & & \\
\hline strongly agree + agree & 377 & 89.98 & 246 & 89.78 & 131 & 90.34 & -0.1828 & 0.8572 \\
\hline disinterested & 29 & 6.92 & 20 & 7.30 & 9 & 6.21 & 0.4191 & 0.6745 \\
\hline disagree + strongly disagree & 13 & 3.10 & 8 & 2.92 & 5 & 3.45 & -0.2968 & 0.7642 \\
\hline
\end{tabular}

$\chi^{2}$ value $=0.2522 ; \mathrm{p}$-value $=0.8815 ; \mathrm{a}=0.05$

(Source: own data collection) 
INTERNATIONAL JOURNAL OF ENTREPRENEURIAL KNOWLEDGE

Issue 1, volume 8, ISSN 2336-2960 (Online)

www.ijek.org

It follows from those statistical calculations that there are no statistically significant differences in the owner 's attitudes to the assertion that he should take into account the moral and ethical implications of his decisions in the context of the size of the business. We reject the H1b hypothesis.

Table 2 The structure of answers to hypothesis H1C

\begin{tabular}{|c|c|c|c|c|c|c|c|c|}
\hline & \multicolumn{2}{|c|}{$\begin{array}{c}\text { TOTAL } \\
419\end{array}$} & \multicolumn{2}{|c|}{$\begin{array}{c}\text { BOHEMIA } \\
284\end{array}$} & \multicolumn{2}{|c|}{$\begin{array}{c}\text { MORAVIA } \\
135\end{array}$} & \multirow[t]{2}{*}{ Z-score } & \multirow{2}{*}{$\begin{array}{l}\text { Z-score } \\
\text { p-value }\end{array}$} \\
\hline & No. & $\%$ & No. & $\%$ & No. & $\%$ & & \\
\hline strongly agree + agree & 377 & 89.98 & 255 & 89.79 & 122 & 90.37 & -0.1853 & 0.8493 \\
\hline disinterested & 29 & 6.92 & 21 & 7.39 & 8 & 5.93 & -0.5534 & 0.5823 \\
\hline disagree + strongly disagree & 13 & 3.10 & 8 & 2.82 & 5 & 3.70 & -0.4892 & 0.6241 \\
\hline
\end{tabular}

$\chi^{2}$ value $=0.5205 ; \mathrm{p}$-value $=0.7709 ; \mathrm{a}=0.05$

(Source: own data collection)

It follows from those calculations that there are no statistically significant differences in the owner's attitudes to the assertion that he should take into account the moral and ethical implications of his decisions in the context of the domicile of the undertaking. We also reject the H1c hypothesis.

Almost $90 \%$ of owners (managers) agree that they should take into account the moral and ethical implications of their decisions and that these responses are not statistically influenced in any way by the size of the company or the location.

\section{The respondent knows the concept of CSR and promotes it in his managerial work}

Almost $44 \%$ of respondents agreed with the statement that the manager knows the concept of CSR and promotes it in his managerial work. In this case, we reject hypothesis $\mathrm{H} 2 \mathrm{a}$, because less than $50 \%$ of respondents completely agreed, resp. agreed with the claim.

Table 3 The structure of answers to hypothesis H2B

\begin{tabular}{|c|c|c|c|c|c|c|c|c|}
\hline & \multicolumn{2}{|c|}{$\begin{array}{c}\text { TOTAL } \\
419\end{array}$} & \multicolumn{2}{|c|}{$\begin{array}{c}\text { MICRO } \\
\text { ENTERPRISE } \\
274\end{array}$} & \multicolumn{2}{|c|}{$\begin{array}{c}\text { SMALL AND } \\
\text { MEDIUM } \\
\text { ENTERPRISE } \\
145\end{array}$} & \multirow[t]{2}{*}{ Z-score } & \multirow[t]{2}{*}{$\begin{array}{l}Z \text {-score } \\
\text { p-value }\end{array}$} \\
\hline & No. & $\%$ & No. & $\%$ & No. & $\%$ & & \\
\hline strongly agree + agree & 184 & 43.91 & 118 & 43.07 & 66 & 45.52 & -0.481 & 0.6312 \\
\hline disinterested & 144 & 34.37 & 88 & 32.12 & 56 & 38.62 & -1.3335 & 0.1835 \\
\hline disagree + strongly disagree & 91 & 21.72 & 68 & 24.82 & 23 & 15.86 & 2.1149 & 0.0349 \\
\hline
\end{tabular}

$\chi^{2}$ value $=4.7983 ; \mathrm{p}$-value $=0.0908 ; \mathrm{a}=0.05$

(Source: own data collection)

The values in the table show that there are no statistically significant differences in the attitudes of the owner to claim that he knows CSR and promotes it in his managerial work depending on the size of the company. Only by looking at the dissenting answers we can see the statistical significance of the differences in the context of the size of the enterprise. We reject hypothesis $\mathrm{H} 2 \mathrm{~b}$.

Table 4 The structure of answers to hypothesis H2C 
INTERNATIONAL JOURNAL OF ENTREPRENEURIAL KNOWLEDGE

Issue 1, volume 8, ISSN 2336-2960 (Online)

www.ijek.org

\begin{tabular}{|c|c|c|c|c|c|c|c|c|}
\hline & \multicolumn{2}{|c|}{$\begin{array}{c}\text { TOTAL } \\
419\end{array}$} & \multicolumn{2}{|c|}{$\begin{array}{c}\text { BOHEMIA } \\
284\end{array}$} & \multicolumn{2}{|c|}{$\begin{array}{c}\text { MORAVIA } \\
135\end{array}$} & \multirow[t]{2}{*}{ Z-score } & \multirow{2}{*}{$\begin{array}{l}\text { Z-score } \\
\text { p-value }\end{array}$} \\
\hline & No. & $\%$ & No. & $\%$ & No. & $\%$ & & \\
\hline strongly agree + agree & 184 & 43.91 & 123 & 43.31 & 61 & 45.19 & -0.3615 & 0.7188 \\
\hline disinterested & 144 & 34.37 & 102 & 35.92 & 42 & 31.11 & 0.9677 & 0.3320 \\
\hline disagree + strongly dis & 91 & 21.72 & 59 & 20.77 & 32 & 23.70 & -0.6795 & 0.4965 \\
\hline
\end{tabular}

$\chi^{2}$ value $=1.0493 ; \mathrm{p}$-value $=0.5918 ; \mathrm{a}=0.05$

(Source: own data collection)

Based on the results, we reject the $\mathrm{H} 2 \mathrm{c}$ hypothesis because there are no statistically significant differences in the attitudes asked to claim that they know the concept of CSR and promote it in their managerial work, in terms of the domicile of the company.

184 owners (managers) agree with the statement that they know the concept of CSR and promote it in their managerial work, but this is not $50 \%$ of respondents. It was again confirmed that in the case of the claim, there are no statistically significant differences in the answers in the context of the size of the company and the registered office, resp. operation.

The implementation of CSR allows the company to gain a competitive advantage in the market and higher customer loyalty

Only $28 \%$ of respondents agree with the statement that the implementation of CSR will allow their company to gain a competitive advantage in the market and higher customer loyalty. We reject hypothesis $\mathrm{H} 3 \mathrm{a}$ because less than $50 \%$ of owners or managers agree with this statement.

Table 5 The structure of answers to hypothesis $\mathbf{H 3 B}$

\begin{tabular}{|c|c|c|c|c|c|c|c|c|}
\hline & \multicolumn{2}{|c|}{$\begin{array}{c}\text { TOTAL } \\
419\end{array}$} & \multicolumn{2}{|c|}{$\begin{array}{c}\text { MICRO } \\
\text { ENTERPRISE } \\
274\end{array}$} & \multicolumn{2}{|c|}{$\begin{array}{c}\text { SMALL AND } \\
\text { MEDIUM } \\
\text { ENTERPRISE } \\
145\end{array}$} & \multirow[t]{2}{*}{ Z-score } & \multirow[t]{2}{*}{$\begin{array}{l}\text { Z.score } \\
\text { p-value }\end{array}$} \\
\hline & No. & $\%$ & No. & $\%$ & No. & $\%$ & & \\
\hline strongly agree + agree & 117 & 27.92 & 74 & 27.01 & 43 & 29.66 & -0.5747 & 0.5687 \\
\hline disinterested & 160 & 38.19 & 100 & 36.50 & 60 & 41.38 & -0.9787 & 0.3271 \\
\hline disagree + strongly disagree & 142 & 33.89 & 100 & 36.50 & 42 & 28.97 & 1.5493 & 0.1211 \\
\hline
\end{tabular}

$\chi^{2}$ value $=2.4169 ; \mathrm{p}$-value $=0.2986 ; \mathrm{a}=0.05$

(Source: own data collection)

The statistical values show that there are no statistically significant differences in the statement that the implementation of CSR allows a company to gain a competitive advantage and higher customer loyalty in the context of the size of the company. We reject the H3b hypothesis.

Table 6 The structure of answers to hypothesis H3C

\begin{tabular}{|c|c|c|c|c|c|c|c|c|}
\hline & \multicolumn{2}{|c|}{$\begin{array}{c}\text { TOTAL } \\
419\end{array}$} & \multicolumn{2}{|c|}{$\begin{array}{c}\text { BOHEMIA } \\
284\end{array}$} & \multicolumn{2}{|c|}{$\begin{array}{c}\text { MORAVIA } \\
135\end{array}$} & \multirow[t]{2}{*}{ Z-score } & \multirow{2}{*}{$\begin{array}{l}\text { Z-score } \\
\text { p-value }\end{array}$} \\
\hline & No. & $\%$ & No. & $\%$ & No. & $\%$ & & \\
\hline strongly agree + agree & 117 & 27.92 & 70 & 24.65 & 47 & 34.81 & -2.1678 & 0.03 \\
\hline disinterested & 160 & 38.19 & 113 & 39.79 & 47 & 34.81 & 0.9793 & 0.327 \\
\hline disagree + strongly disagree & 142 & 33.89 & 101 & 35.56 & 41 & 30.37 & 1.0495 & 0.2937 \\
\hline
\end{tabular}


INTERNATIONAL JOURNAL OF ENTREPRENEURIAL KNOWLEDGE

Issue 1, volume 8, ISSN 2336-2960 (Online)

www.ijek.org

$\chi^{2}$ value $=4.7082 ; p$-value $=0.9498 ; a=0.05$

(Source: own data collection)

In Table 6 we can see that in the case of positive answers there are statistically significant differences in the answer in the context of the geographical location of the company. In other cases, however, there are no statistically significant differences in responses. Based on the view of the overall answers through the values of $\chi^{2}$, we reject the hypothesis $\mathrm{H} 3 \mathrm{c}$.

On the question of the implementation of CSR and the positive benefits in a competitive environment and employee loyalty, only $28 \%$ of respondents agree with the statement. In the case of answers when assessing the domicile of the company, we see the statistical significance of positive answers, which in the case of Moravia is more than 10\% higher. From these results we can conclude that in Moravia they consider CSR more to be a favorable factor in increasing competitive advantage.

\section{CSR enables the company to acquire satisfied, loyal and motivated employees}

In the case of this question, the consensus answers are 131 (about 31\%). In this case, we reject hypothesis $\mathrm{H} 4 \mathrm{a}$, because only $31 \%$ of managers agree with the statement that the concept of CSR allows to obtain satisfied, loyal and motivated employees.

Table 7 The structure of answers to hypothesis H4B

\begin{tabular}{|c|c|c|c|c|c|c|c|c|}
\hline & \multicolumn{2}{|c|}{$\begin{array}{c}\text { TOTAL } \\
419\end{array}$} & \multicolumn{2}{|c|}{$\begin{array}{c}\text { MICRO } \\
\text { ENTERPRISE } \\
274\end{array}$} & \multicolumn{2}{|c|}{$\begin{array}{c}\text { SMALL AND } \\
\text { MEDIUM } \\
\text { ENTERPRISE } \\
145\end{array}$} & \multirow[t]{2}{*}{ Z-score } & \multirow[t]{2}{*}{$\begin{array}{l}Z \text {-score } \\
\text { p-value }\end{array}$} \\
\hline & No. & $\%$ & No. & $\%$ & No. & $\%$ & & \\
\hline strongly agree + agree & 131 & 31.26 & 82 & 29.93 & 49 & 33.79 & -0.8121 & 0.4179 \\
\hline disinterested & 158 & 37.71 & 102 & 37.23 & 56 & 38.62 & -0.2802 & 0.7795 \\
\hline disagree + strongly disagree & 130 & 31.03 & 90 & 32.85 & 40 & 27.59 & 1.1073 & 0.267 \\
\hline
\end{tabular}

$\chi^{2}$ value $=1.4379 ; \mathrm{p}$-value $=0.5097 ; \mathrm{a}=0.05$

(Source: own data collection)

We reject the established hypothesis $\mathrm{H} 4 \mathrm{~b}$, because on the basis of statistical calculations there are no statistically significant differences in the attitudes of the owner in the context of the size of the company.

Table 8 The structure of answers to hypothesis H4C

\begin{tabular}{|c|c|c|c|c|c|c|c|c|}
\hline & \multicolumn{2}{|c|}{$\begin{array}{c}\text { TOTAL } \\
419\end{array}$} & \multicolumn{2}{|c|}{$\begin{array}{c}\text { BOHEMIA } \\
284\end{array}$} & \multicolumn{2}{|c|}{$\begin{array}{c}\text { MORAVIA } \\
135\end{array}$} & \multirow[t]{2}{*}{ Z-score } & \multirow{2}{*}{$\begin{array}{l}\text { Z-score } \\
\text { p-value }\end{array}$} \\
\hline & No. & $\%$ & No. & $\%$ & No. & $\%$ & & \\
\hline strongly agree + agree & 131 & 31,26 & 79 & 27,82 & 52 & 38,52 & $-2,2073$ & 0,0271 \\
\hline disinterested & 158 & 37,71 & 108 & 38,03 & 50 & 37,04 & 0,1956 & 0,8415 \\
\hline disagree + strongly disagree & 130 & 31,03 & 97 & 34,15 & 33 & 24,44 & 2,008 & 0,0444 \\
\hline
\end{tabular}

$\chi^{2}$ value $=6,1566 ; p$-value $=0,0460 ; a=0,05$

(Source: own data collection) 
INTERNATIONAL JOURNAL OF ENTREPRENEURIAL KNOWLEDGE

Issue 1, volume 8, ISSN 2336-2960 (Online)

www.ijek.org

In terms of the domicile of the company, we see that there are statistically significant differences in the case of positive answers, as well as in the case of non-positive answers. We accept hypothesis $\mathrm{H} 4 \mathrm{c}$ on the basis of positive values of $\chi^{2}$.

In the question of the concept of CSR and its positive impact on co-workers, we see that there are statistically significant differences in the context of the geographical location of the company, again in favor of Moravia. Unfortunately, the managers' consensus on this statement alone is less than a third only $31 \%$.

\section{In which areas does your company operate responsibly?}

Respondents were able to answer this question by multiple choice of options, a minimum of 1 to a maximum of 3 . In the case of a breakdown into individual options, the answers were as follows:

- high quality of firm's products - $62 \%$ consequently 261 respondents

- work environment - answered 63 respondents (15\%)

- environment (ecological products, etc.) - answered 10\% of respondents (42 companies)

- community - 53 respondents (13\%).

For better visualization, we show the answers in a graph.

Graph 1 Structure of responses to T5

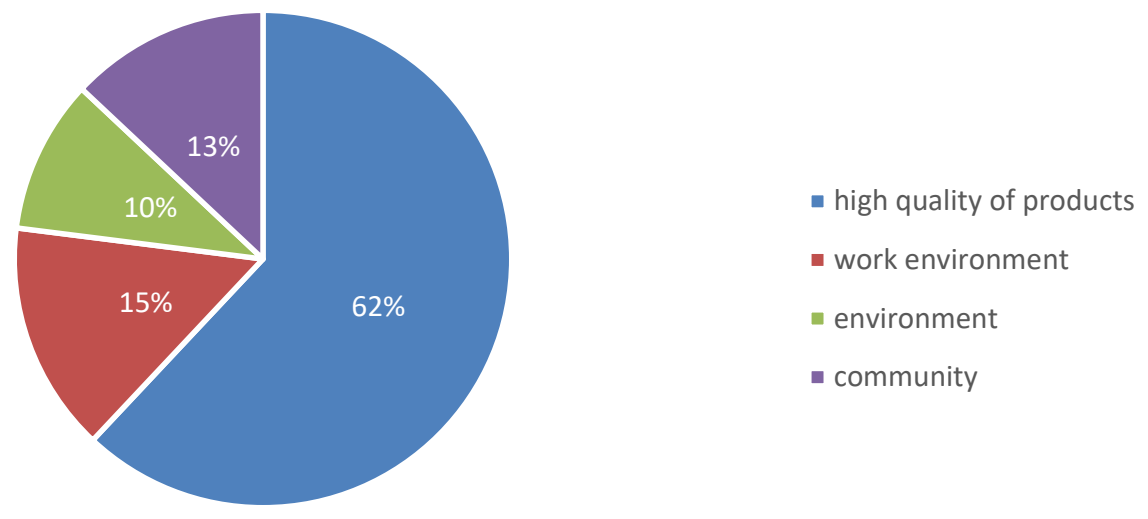

(Source: own data collection)

\section{DISCUSION}

The research shows that more than $90 \%$ of respondents agree with the statement that the owner (manager) should take into account the moral and ethical consequences of their decisions, but only $44 \%$ of managers commented positively (approvingly) on the concept and its knowledge. Only 28\% agreed with the statement about the competitive advantage resulting from the introduction of the CSR concept in the company, but many managers were unable to take a position - disinterested (up to $39 \%$ ). In the case of a positive impact on co-workers, the number of positive answers is also low, only $31 \%$ of respondents, which is almost equal to the non-positive answers. 


\section{INTERNATIONAL JOURNAL OF ENTREPRENEURIAL KNOWLEDGE}

Issue 1, volume 8, ISSN 2336-2960 (Online)

www.ijek.org

In terms of enterprise size, we can conclude, based on statistical calculations, that there are no statistically significant differences in the overall responses for micro-enterprises and small and medium-sized enterprises.

According to the geographical scope of the company, we can see differences in the answers to the questions of gaining a competitive advantage, satisfaction and loyalty of its own employees, through the implementation of CSR, a higher proportion of positive answers from Moravia. The percentage difference oscillates around $10 \%$.

Compared to research conducted in 2016 (see Hodinková and Sádovský), the introduction of CSR will cause increased attractiveness for investors, strengthen market position, etc., increase confidence, improve employer-employee relations, etc., understand these aspects have a better understanding of businessmen in Moravia. The question remains, why? Whether it is caused by other factors or it is a "local mentality" -We would recommend doing more research on these issues. The results show that only $28 \%$ of entrepreneurs agree with the statement that the activities of the CSR concept will allow them to gain a competitive advantage and increase customer loyalty.

Relative to the 2008 Business Leaders Forum study for small businesses (micro + small businesses), our research shows that $44.3 \%$ of SMEs surveyed (162 out of 366) are familiar with the concept of CSR and promote it in their management practice. Compared to the research in 2008, the increase is 7.3\% (in 2008, $37 \%$ of micro and small enterprises answered positively to a similar question). In comparison with medium-sized enterprises, our research recorded a drop of $19.5 \%$ with a result of $41.5 \%$ (22 out of 53) compared to research in 2008 with a value of $61 \%$. In the case of Chinese family SMEs (Xue, $\mathrm{Yu}, \mathrm{Xu}$, 2019), up to $96 \%$ of respondents heard about the concept of CSR.

Contrary to the opinions published by Pavlík and Bělč́k (2010) of CSR activities - especially sponsorship - our results are in conflict, because only $13 \%$ of respondents work socially responsibly in the community (support for corporate giving).

From research, it is worth pointing out the constant need to inform entrepreneurs about the concept of CSR. As we can see from the graph, most companies promote the environmental nature of CSR. Compared to Chinese family SMEs, we lag behind in employee care - only $15 \%$ of companies said that they behave responsibly in the context of the work environment, while in the surveyed companies in China it is up to 4 times more $-60 \%$.

According to Hadj et al. (2020) CSR can be seen as a balanced style of management given the benefits of stakeholders. In the case of customer and supplier orientation, only $28 \%$ of entrepreneurs agree with the statement, in the case of employees only 31\% take the position. In general, Czech entrepreneurs do not hold the opinion that the implementation of CSR can have an impact in this area.

If the government have to support the introduction of the CSR concept, it could make this conditional on various tax benefits. For this purpose, it would be beneficial to carry out specific research focused on CSR and to find out e.g. the needs of entrepreneurs from the state, which would motivate to a higher number of socially responsible companies in the Czech Republic, as there is a lack of other research that deals with the Czech Republic. The authors also see the need for greater awareness of companies by promoters of CSR ideas.

\section{CONCLUSIONS}

The results showed that although the manager should take into account the ethical and moral implications of his decisions, less than half of the respondents are familiar with the concept of CSR and enforce it in 


\section{INTERNATIONAL JOURNAL OF ENTREPRENEURIAL KNOWLEDGE}

Issue 1, volume 8, ISSN 2336-2960 (Online)

www.ijek.org

their management practice and ultimately managers cannot identify positive benefits from CSR implementation - answers whose values oscillate around 30\%. The findings show that there are no statistically significant differences in the answers of managers depending on the size of the company this proves that micro, small and medium enterprises, respectively their managers do not differ in their attitudes to the topic of CSR. In the case of the geographical scope of the corporation, we noticed significant differences in attitudes in claiming that the introduction of CSR allows the company to acquire satisfied, loyal and motivated employees. According to research, entrepreneurs in Moravia are more aware of the importance of CSR in the context of a satisfied and loyal employee. Most entrepreneurs work responsibly in the production of quality products while adhering to the company's code of ethics.

It is important to draw attention to the low values of positive responses to the positive aspects resulting from the implementation of CSR in the field of competitive position and supplier-customer relations, respectively in the perception of the corporation by its own employees. Less than half of entrepreneurs know the concept of CSR and promote it in their practice. This only contributes to the need for information and promotion of CSR in the SME environment. Most entrepreneurs work socially responsibly in adhering to the quality of their products and the code of ethics in their production. It is interesting to note that only almost 15\% implement CSR in the context of their own employees.

Finally, it should be added that due to the limited scope of work, it was not possible to examine and evaluate several aspects, e.g. answers from the point of view of the achieved education of the entrepreneur, the length of the business or other aspects concerning the person of the entrepreneur. In its structure, the work dealt mainly with the search for answers in the context of the company and did not reflect on the personality of the entrepreneur. In the future, it is possible to continue research and analysis to achieve a comprehensive view of CSR issues for SMEs in the Czech Republic.

The results presented in the paper can be determined in advance by managers - entrepreneurs who are considering the introduction of the concept of CSR in your practice, you can see other attitudes of other entrepreneurs who make decisions. On the other hand, the document offers a practical tool for politicians who negotiate various forms of SME support to ensure the implementation of the CSR concept.

\section{REFERENCES}

Bikefe, G., Zubairu, U., Araga, S., Maitala, F., Ediuku, E. \& Anyebe, D. (2020). Corporate Social Responsibility (CSR) by small and medium enterprises (SMEs): a systematic review. Small Business International Review. 4(1), 16-33. DOI: 10.26784/sbir.v4i1.243.

Caroll, A. B. (2016). Carroll's pyramid of CSR: taking another look. International Journal of Corporate Social Responsibility, 1(3). DOI: 10.1186/s40991-016-0004-6.

Caroll, A. B. (2008). A History of Corporate Social Responsibility: Concepts and Practices. In: A. Crane (Ed.), The Oxford handbook of corporate social responsibility (pp. 19-47). Oxford University Press.

Castka, P., Balzarova, M. A.,\&Sharp, J. M. (2004). How can SMEs effectively implement the CSR agenda?: A UK case study perspective. Corporate Social Responsibility and Environmental Management, 11(2), 140-149. DOI:10.1002/csr.062. ISSN 1535-3966.

Česká republika. (2019). Zpráva o vyvoji podnikatelského prostředí v České republice v roce 2018, 2019. In: Ministerstvo průmyslu a obchodu České republiky. https://www.mpo.cz/cz/podnikani/male-a-stredni-podnikani/studie-a-strategicke-

dokumenty/zprava-o-vyvoji-podnikatelskeho-prostredi-v-ceske-republice-v-roce-2018--251001/

Európska únia. (2011). Oznámenie komisie Európskeho parlamentu, Rade, Európskemu hospodárskemu a sociálnemu výboru a Výboru regiónov - Obnovená stratégia EÚ pre sociálnu zodpovednost' 


\section{INTERNATIONAL JOURNAL OF ENTREPRENEURIAL KNOWLEDGE}

Issue 1, volume 8, ISSN 2336-2960 (Online)

www.ijek.org

podnikov na obdobie rokov 2011-2014. https://op.europa.eu/en/publication-detail//publication/ae5ada03-0dc3-48f8-9a32-0460e65ba7ed/language-sk

Flammer, C., Lou, J. (2017). Corporate social responsibility as an employee governance tool: Evidence from a quasi-experiment. Strategic Management Journal, 38(2), 163-183. https://doi.org/10.1002/smj.2492.

Friedman, M. (1993). Kapitalismus a svoboda. Liberální institut.

Gelbman, U. (2010). Establishing Strategic CSR in SMEs: an Austrian CSR Quality Seal to Substantiate the Strategic CSR Performance. Sustainable Development, 18(2), 90-98. DOI: 10.1002/sd.448.

Gorgenyi-Hegyes, M., Fekete-Farkas, M. (2019). Internal CSR as a strategic management tool in reduction of labour shortages. Polish journal of managemet studies, 19(2), 167-181. DOI: 10.17512/pjms.2019.19.2.14

Hadj, T. B., Omri, A., \& Al-Tit, A. (2020). Mediation role of responsible innovation between CSR strategy and competitive advantage: Empirical evidence for the case of Saudi Arabia enterprises. Management Science Letters, 10(4), 747-762. https://doi.org/10.5267/j.msl.2019.10.022

Hodinková, M.Sadovský, Z. (2016). The benefits of corporate social responsibility introduction in small and medium-sized enterprises: a systematic review of the literature. Business: Theory and Practice, 17(4), 345-352. DOI: https://doi.org/10.3846/btp.17.11130.

Chen, J., Liu, J., Qin, J. (2019). Corporate social responsibility and capacity selection. Transformations in Business \& Economics, 18 (3C(48C)), 530-546.

Chládková, H. (2015). Selected Approaches to the Business Environment Evaluation. Acta Universitatis Agriculturae Et Silviculturae Mendelianae Brunensis, 63(2), 515-523. DOI: $10.11118 /$ actaun201563020515.

Ipsos.(2019). Veřejnost očekává od CSR aktivit firem zejména ochranu životního prostredí a férové chovaník zaměstnancưm: https://www.ipsos.com/sites/default/files/ct/news/documents/201905/tiskova_zprava_ipsos_28_05_2019_csr.pdf

Ipsos. (2017). CSR \& Reputation research 2016: Vybrané výsledky výzkumu - veřejná část https://www.ipsos.com/sites/default/files/2017-

12/ipsos_csr_reputation_research_2016_vybrane_vysledky_z_verejne_casti_vyzkumu.pdf

Jones, D. (2014).Společenskyvodpovědnévchování se firmámvvyplácí. Management Press.

Kašparová, K.,Kunz, V. (2013).Modernívpřístupy ke společenské odpovědnosti firem a CSR reportování. Grada.

Kowalska, K. (2016). Network organizations and corporate social responsibility. Oeconomia Copernicana, 7(4), 653-668. https://doi.org/10.12775/OeC.2016.036

Krajnakova, E., Navickas, V., \& Kontautiene, R. (2018). Effect of macroeconomic business environment on the development of corporate social responsibility in Baltic Countries and Slovakia. Oeconomia Copernicana, 9(3), 477-492. https:// doi.org/10.24136/oc.2018.024

Kuldová, L. (2010). Společenská odpovědnost firem: [eticképodnikání a sociálníodpovědnost v praxi]. OPS.

Kunz, V. (2012).Společenská odpovědnost firem. Grada.

Lee, K. H., Herold, D. M.,\&Yu, A. L. (2016). Small and Medium Enterprises and Corporate Social Responsibility Practice: A Swedish Perspective. Corporate Social Responsibility and Environmental Management, 23(1), 87-99. DOI: 10.1002/csr.1366.

Lu, J.T., Ren, L.C., Qiao, J.Y., Lin, W.F., He, Y.F. (2019). Female Executives and Corporate Social Responsibility Performance: a Dual Perspective of Differences in Institutional Environment and Heterogeneity of Foreign Experience. Transformations in Business \& Economics, 18 (2(47)), 174179.

OECD. (2020). Enterprises by business size (indicator). DOI: 10.1787/31d5eeaf-en.

OECD. (2001). Corporate responsibility: private initiatives and public goals. In Mexico Hungary Korea. https://doi.org/10.1787/9789264193062-en.

Pavlík, M.,Bělčík, M. (2010). Společenská odpovědnos torganizace: CSR v praxi a jak s nímdál. Grada. 
INTERNATIONAL JOURNAL OF ENTREPRENEURIAL KNOWLEDGE

Issue 1, volume 8, ISSN 2336-2960 (Online)

www.ijek.org

Porter, M. E., Kramer, M. R. (2006). Strategy and Society: The Link Between Competitive Advantage and Corporate Social Responsibility. Harvard Business Review, 84(12), 01-13.

Prskavcová, M., Maršíková, K., Řehořová, P. (2007). Problematika Corporate Social Responsibility se zaměřením na lidský kapitál, Gender Studies a environmentální management. Technická univerzita v Liberci.

Tetřevová, L. (2017). Společenská odpovědnost firem společensky citlivých odvětví. Grada Publishing.

Vo, L. Ch., Delchet-Cochet, K.,\&Akeb, H. (2015). Motives Behind The Integration Of CSR Into Business Strategy: A Comparative Study In French SMEs. The Journal of Applied Business Research, 31(5), 1975-1986.

Xue, K., Yu, M.,\& Xu, S. (2019). Corporate social responsibility and Chinese family-owned small- and medium-sized enterprises. Social Behavior and Personality, 47(3).

Yunus, M.,Weber, K. (2010). Building social business: the new kind of capitalism that serves humanity's most pressing needs. Public Affairs.

\section{BRIEF DESCRIPTION OF AUTHOR/AUTHORS:}

\section{Zdenko Metzker}

Master student in Department of Business Administration, Faculty of Management and Economics Thomas Bata University in Zlin, Mostní 5139, Zlín, Czech Republic, e-mail: z_metzker@utb.cz.

\section{Justas Streimikis}

Ph.D. student at Lithuanian Institute of Agrarian Economics, Division of Farm and Enterprise Economics. A. Vivulskio g. 4A-13, 03220 Vilnius, Lithuania, e-mail: justas.streimikis@gmail.com. He also works as an assistant at the Faculty of Management and Finance in the University of Economics and Human Science in Warsaw, in Poland. His main field of research is Corporate Social Responsibility and various issues of sustainability. 